\title{
INSTITUTIONAL SUPPORT FOR STRENGTHENING ENTREPRENEURSHIP IN AGRICULTURAL PRODUCTION OF THE REPUBLIC OF SERBIA
}

\author{
Vladimir Ilić, ${ }^{1}$ Ivan Bauer², Anastazija Tanja Đelić3 ${ }^{3}$,Aleksandar Neškovićc
}

\begin{abstract}
Developed countries reaffirm the role of agriculture in the functioning of the entire economy, emphasizing the importance of agricultural production. Faced with the need for greater investment in agriculture while directing new investments into underdeveloped rural areas, transitional countries must realistically assess their potentials and limitations in this area. The aim of the study is to define the characteristics of the SME sector during structural changes in agriculture, which is one of the drivers of economic development of Serbia. This study analyzes the current state of the sector of small and medium enterprises and entrepreneurs in agriculture and examines indicators that point to their development. How to encourage the development of agricultural production in a country that has experienced a complete economic collapse? Why do incentives to entrepreneurship and agricultural production in the Republic of Serbia have no expected effects? Institutions of the Government of the Republic of Serbia have created a whole spectrum of economic and fiscal incentives after the 5th October changes, but the effects of such programs are limited. Political managing of funds, institutions and ministries reduces the efficiency and transparency of the program, which greatly reduces the scope and importance of these programs in a healthier business environment. Serbia's determination to continue European integration obliges economic policy makers to comply with the most important economic development documents and strategies accepted by EU countries. General economic development must provide the conditions for further successive expansion of agricultural production in Serbia, while at the same time undertaking measures for the modernization of agricultural holdings as part of integral development.
\end{abstract}

1 Vladimir Ilić, PhD, Assistant Professor, Neimar V, Kneginje Zorke Street 2, 11000 Belgrade, Serbia, Phone: +381 113084 103, E-mail: vladimir.ilic@neimarv.rs

2 Ivan Bauer, Ph.D., National Parlament of the Republic of Serbia, Nikola Pašić Square 13, 11000 Belgrade, Serbia, Phone: +381 113094 094, E-mail: ivan.bauer@parlament.rs

3 Anastazija Tanja Đelić, Ph.D., Ministry of Finance, Kneza Miloša Street 20, 11000 Belgrade, Serbia, Phone: +381 113642 842, E-mail: tanja.djelic@gmail.com

4 Aleksandar Nešković, M.A., Ministry of Finance-Customs Administration, Zoran Đinđić Boulevard 155a, 11070 Belgrade, Serbia, Phone: +381 649946 236, E-mail: neskovica@upravacarina.rs

EP 2017 (64) 4 (1537-1554) 
Key words: agriculture, production, institutional support, economic development, Serbia;

JEL: $Q 16, M 24$

\section{Introduction}

The Republic of Serbia is a country of incomplete transition, which has degraded the economic structure inherited from the period of common socialist Yugoslavia, while leaving little space for entrepreneurship or any other form of private, market economy. The irresponsible political elites during the last decade of the twentieth century and the first decade of the twenty-first century, often associated with criminal and tycoon structures, allowed the inexorable collapse of the country's economy, whose consequences will be felt for many more years. The wars of the 1990s, sanctions and speculative privatization pushed Serbia to the very end of European countries in many areas. For example, industrial production in Serbia today barely reaches $40 \%$ of industrial production in 1989.

Under these circumstances, a logical question is raised - how to develop the economy and ensure sustainable growth over a longer period. The most common answers that can be heard are slowly being converted into phrases such as "structural reforms are necessary..., a serious turnover in fiscal and monetary policy... creating an environment for attracting foreign investment and creating new jobs. 2 All of these phrases are usually heard during political campaigns for elections, and after that, optimism and energy for change are blurred by giving way to an powerful and politicized bureaucracy that "does everything" to kill any desire for entrepreneurship or any other initiative to create the conditions for running a business. For objective reasons, there has been a shift over the past ten years, especially when it comes to supporting foreign investors by facilitating many procedures, building the necessary infrastructure, amending regulations and other activities. According to many estimates, from the beginning of the nineties to the present, the transition has "swallowed" more than half a million jobs, which in Serbia in the late eighties were almost 3 million. According to official statistics, nowadays there are over 2.1 million workers in Serbia, of which only 1.7 million workers pay taxes and contributions from which the total population of 7 million people, including 1.7 million pensioners, is financed. ${ }^{5}$

According to the number of entrepreneurs, we could say that Serbia is a country of entrepreneurs, considering that on June 1, 2016 there was 217.035 of them. ${ }^{6}$ This data suggests that more than every tenth employee in Serbia is an entrepreneur, on what might envy us many developed countries with a centuries-long tradition of entrepreneurship. Unfortunately, this information although accurate, is saying something completely different

5 Data of the Statistical Office of the Republic of Serbia for 2016. http://www.rzs.gov.rs, accessed on: 07.11.2017

6 According to the Serbian Business Registers Agency : http://www.apr.gov.rs/, accessed on: 08.11.2017. 
- a wave of layoffs and the consequences of speculative privatizations have forced many people out of work and on the verge of existence to enter into entrepreneurial waters. Many have failed in their attempts to become "their own bosses" because of the lack of any institutional support from the state, as well as because of their inexperience, unpreparedness and inability to access sources of financing. Entrepreneurship in Serbia has developed spontaneously and without special inventiveness. People would most often copy something they thought was a "successful" business. This "copywriting entrepreneurship" brought us thousands of exchange offices, coffee shops, bakers, pizzerias, betting shops and cafes. Most of them were closed much more quickly than it took the procedures for opening them. Large economies that usually accompany small satellite entrepreneurial activities has long disappeared, which further narrowed the opportunities for new entrepreneurs. The state has failed to open channels to international markets, so entrepreneurs in Serbia are closed within a shallow and undeveloped market without enough experience and funding, looking for real business activity. Fortunately, there are also many good examples of successful small businesses that have found a place under the sun, primarily through innovation and connecting to regional and global markets.

When it comes to the role of the state in encouraging micro, small and medium enterprises and entrepreneurs in agriculture, things have improved in recent years by finally raising awareness that financial and nonfinancial support to small business is necessary in order to survive and continue to develop. For these reasons, previous 2016, was declared "the year of entrepreneurship" in Serbia, which is certainly a step forward in the right direction. It remains to be awaited and evaluated the effects of such a goal. ${ }^{7}$

\section{Limitations and prospects for the development of agrarian entrepreneurship}

Serbia, like the rest of the world, is seriously shaken by the global economic crisis, which is ending several times, but eight years after the outbreak of this crisis, it is clear that this long-awaited end is not visible. It's no longer the point of crisis only in poor economic indicators, the capabilities of the entire country's bankruptcy, growing unemployment and simply dropping the standard of living. At the heart of the latest economic crisis is the unsustainability of the world economic order, which for decades raises the gap between the rich and the poor. A number of social, political, geo-strategic, religious and other factors have been incorporated into the latest economic crisis of the globalized world. Liberalism, as the concept and key mantra of globalization, abandons today its fiercest supporters and theorists facing the realities of the modern world and threats such as catastrophic climate changes, limited resources, potential regional (and wider) conflicts and migrations from the East to the West. The current crisis in Syria and the wave of refugees from that part of the world to Europe is just the announcement of a "great migration" that will certainly come if the model of the global economic order is not abandoned.

7 http://www.kombeg.org.rs/Slike/UdrPoljoprivreda/2014/februar/Strategija\%20 Poljoprivrede\%20i\%20ruralnog\%20razvoja\%20RS\%202014\%20Nacrt\%20word.pdf, accessed on: 09.11.2017.

EP 2017 (64) 4 (1537-1554) 
In the long run, economically sustainable development of Serbia is not possible in the current way through GDP growth based on the growth of domestic demand caused by foreign credits and privatization revenues. The consequences of such growth are the constant deficit of the foreign trade balance, the growth of wages above the productivity growth and the constant inflationary pressures. In the current concept of development, more than $4 / 5$ of capital inflows from loans and foreign direct investments went to non-resident sectors (banking, trade, real estate, transport, telecommunications), while for the sectors of exchange (agriculture, industry, mining), the only ones that can actually correct the foreign trade imbalance, remained only $1 / 5$ capital. This situation is unsustainable, especially since we can no longer count on the privatization proceeds and additional borrowing. This period is over and there is no other way than to attract foreign direct investments in the aforementioned exchange sectors in all areas and activate entrepreneurship with our own capital in this direction. (Tesić et al., 2015)

From the economic crisis to the present, we have seen a significant drop in GDP, resulting in a lack of foreign direct investment (FDI). In this way, one of the most important factors of Serbia's growth over the whole period is missing or decreasing (from about 2.5 billion dollars in 2008 to about 1.2 billion dollars in 2014). The slowdown in foreign direct investment is a consequence of the global crisis, but, on the other hand, is the result of the lack of structural reforms and the creation of a healthy business environment. The unreformed public sector in Serbia is becoming a big ballast and stone around the neck, for the budget of the Republic and for economic growth. Public sector losses, redundancy, over-indebtedness of public enterprises, political governance and unwillingness to reform will make every effort difficult for development.

The insufficient growth of the GDP of Serbia in the last decade, which is on average below $1 \%$, does not provide a minimum chance of joining the developed countries of the EU, on the contrary, it increases the relative lag behind of Serbia. This circumstance provides arguments in favor of encouraging the development of SMEs in agriculture as the only realistic and sustainable economic development options "(Nešković, 2016). Therefore, not only investments from abroad are sufficient, it is necessary to activate one's own potentials that lie primarily in creative and relatively educated people ready (and compelled) to fight on the market and to ensure the existence not only for their family, but also for a large number unemployed who could recruit in a relatively short time. Serbia must recognize this opportunity and provide conditions for their association, growth and development (Tesić et al., 2015). As state does not regret funding to encourage investment from abroad, it must equally find resources to activate the potential of our entrepreneurs and small businesses. In the next part of this study, we will analyze the incentives provided by Serbia to the development of agricultural entrepreneurship through its institutions. 


\section{Strategic efforts of the Republic of Serbia towards the development of SME in the field of agriculture}

Today, economic policy makers in Serbia are becoming aware that, for the sake of false social peace and short-term political benefits, they wasted tens of billions of euros while maintaining in life state-owned enterprises - socialist mammoths such as "Zastava", "Železara", "RTB", "Petrohemija", "PKB", "Resavica" and many others. The decennial protection of these companies from commercial creditors, bankers and taxpayers has created the structures of "interest-related management and trade unions" with the great blackmailing potential of the simple formula "You give us the money, we vote for you and create social peace". The price of such an arrangement was expensive - almost all privatization revenues and several billion of euros of indebtedness went missing, and neither social peace nor money.

On the other hand, the private sector of Serbia, without any support, sought its place on the market with "protected state-owned enterprises". After 2000, it began with the creation of various institutional arrangements for support to the private sector, primarily the SME sector. At this point, we will look at several key institutions and mechanisms of support to entrepreneurship of Serbia, in an attempt to assess the effectiveness and effects of different financial and non-financial measures "(Nešković et al., 2016). The key institutions of support that we will mention here are the Government of Republic of Serbia and its agencies such as the National Employment Service of Republic of Serbia (NES), the Development Fund, the Serbian Chamber of Commerce and the Serbia Investment and Export Promotion Agency - SIEPA (today the Development Agency of Serbia - RAS). Entrepreneurship is also encouraged by various other institutions outside the public sector (such as the Foreign Investors Council), as well as by various associations of entrepreneuers, farmers, non-governmental sector and others. However, the subject of this study is the institutional, state aid to entrepreneurship and therefore it will be in the focus of this analysis.

The role of the Government of the Republic of Serbia in creating a business environment and support is of utmost importance, bearing in mind the resources and power it has. The strategy for supporting the development of small and medium-sized enterprises, entrepreneurship and competitiveness for the period from 2015 to $2020^{8}$ (hereinafter the Strategy) was adopted by the Government of the Republic of Serbia on March 26, 2015. This is a key document that should provide a strategic framework and continuity with previously adopted documents, and in particular with the Development Strategy for Competitive and Innovative Small and Medium Enterprises for the period 2008-

8 http://www.privreda.gov.rs/wp-content/uploads/2015/06/Strategija-mala-i-srednjapreduzeca.pdf, accessed on: 08.11.2017.

EP 2017 (64) 4 (1537-1554) 
$2013^{9}$ (hereinafter: Strategy 08-13), whose time period is over.

The strategy relies on the already established EU policy in the field of entrepreneurship and competitiveness, and above all on the Europe 2020 Strategy Paper and the Small Business Act. The following table provides a clear indication of the connection between the European and Serbian strategic documents (Table 1).

Table 1. The connection between the Strategy and the Small Business Act ${ }^{10}$

\begin{tabular}{|c|c|}
\hline Small Business Act & Strategy \\
\hline $\begin{array}{l}\text { 1. Principle: Create an } \\
\text { environment in which } \\
\text { entrepreneurs and family } \\
\text { businesses can thrive and } \\
\text { entrepreneurship is rewarded }\end{array}$ & $\begin{array}{l}\text { Pillar } 3 \text { Continuous development of human resources } \\
\text { Dimension } 1 \text { Measure 3: Development of the non-formal education } \\
\text { system for improving knowledge and skills } \\
\text { Dimension } 2 \text { Measure 1: Introduction of entrepreneurial education } \\
\text { into all levels of the educational system of the Republic of Serbia } \\
\text { Dimension } 2 \text { Measure 2: Education and training of teachers for } \\
\text { entrepreneurship } \\
\text { Pillar } 6 \text { Development and promotion of the entrepreneurial spirit } \\
\text { and encouraging female entrepreneurship, youth and social } \\
\text { entrepreneurship }\end{array}$ \\
\hline $\begin{array}{l}\text { 3. Principle: Design rules } \\
\text { according to the "Think Small } \\
\text { First" principle }\end{array}$ & $\begin{array}{l}\text { Pillar } 1 \text { Improving the business environment } \\
\text { Dimension 1: Establishing an incentive regulatory framework in line } \\
\text { with the needs and capabilities of the SME } \\
\text { Dimension } 3 \text { Measure 1: Obligatory inclusion of the representatives } \\
\text { of the economy in the process of adopting regulations and public } \\
\text { policies and increasing the predictability of changes in the terms of } \\
\text { business } \\
\text { Dimension } 3 \text { Measure 2: Creation of the Council for Small and } \\
\text { Medium Enterprises, Entrepreneurship and Competitiveness } \\
\text { Dimension } 3 \text { Measure } 4 \text { : Inserting the impact test on small and } \\
\text { medium enterprises in the analysis of the effects of regulations }\end{array}$ \\
\hline $\begin{array}{l}\text { 4. Principle: Make public } \\
\text { administrations responsive to } \\
\text { SMEs' needs }\end{array}$ & $\begin{array}{l}\text { Pillar } 1 \text { Improving the business environment } \\
\text { Dimension } 2 \text { Measure 1: Amendments to the regulatory framework } \\
\text { in the implementation of administrative procedures in state } \\
\text { administration bodies, autonomous provinces and local self- } \\
\text { governments } \\
\text { Dimension } 2 \text { Measure 2: Continuation of the work on strengthening } \\
\text { the electronic administration system } \\
\text { Dimension } 2 \text { Measure 3: Establishing a one-stop-shop system for } \\
\text { providing as many services as possible }\end{array}$ \\
\hline
\end{tabular}

9 Stategija za podršku razvoju malih i srednjih preduzeća, preduzetništva i konkurentnosti za period od 2015. do 2020. godine, Vlada Republike Srbije, Službeni glasnik RS, Srbija, broj 55/11, 2014,(avalaible at: http://www.privreda.gov.rs/wp-content/uploads/2015/06/ Strategija-mala-i-srednja-preduzeca.pdf) accessed on: 08.11.2017.

10 http://www.privreda.gov.rs/wp-content/uploads/2015/06/Strategija-mala-i-srednja preduzeca.pdf, accessed on: 08.11.2017. 


\begin{tabular}{|c|c|}
\hline Small Business Act & Strategy \\
\hline $\begin{array}{l}\text { 5. Principle: Adapt public policy } \\
\text { tools to SME needs }\end{array}$ & $\begin{array}{l}\text { Pillar } 2 \text { Improving access to funding sources } \\
\text { Dimension } 3 \text { Measure 3: Raising awareness among entrepreneurs } \\
\text { and all other stakeholders about the availability and characteristics } \\
\text { of non-banking financial instruments } \\
\text { Pillar } 4 \text { Strengthening the sustainability and competitiveness of SME } \\
\text { Dimension } 1 \text { Measure 3: Further development of business services } \\
\text { for SME } \\
\text { Pillar } 1 \text { Improving the business environment } \\
\text { Dimension } 2 \text { Measure 5: Improving conditions for participation of } \\
\text { SME in public procurement }\end{array}$ \\
\hline $\begin{array}{l}\text { 6. Principle: Facilitate SMEs' } \\
\text { access to finance and develop a } \\
\text { legal and business environment } \\
\text { supportive to timely payments in } \\
\text { commercial transactions }\end{array}$ & Pillar 2 Improving access to funding sources \\
\hline $\begin{array}{l}\text { 7. Principle: Help SMEs } \\
\text { to benefit more from the } \\
\text { opportunities offered by the } \\
\text { Single Market }\end{array}$ & $\begin{array}{l}\text { Pillar } 5 \text { Improving access to new markets } \\
\text { Dimension 2: Reducing and overcoming technical barriers to trade }\end{array}$ \\
\hline $\begin{array}{l}\text { 8. Principle: Promote the } \\
\text { upgrading of skills in SMEs and } \\
\text { all forms of innovation }\end{array}$ & $\begin{array}{l}\text { Pillar } 4 \text { Strengthening the sustainability and competitiveness of SME } \\
\text { Dimension } 1 \text { Measure 4: Further development of training for } \\
\text { potential and existing entrepreneurs } \\
\text { Pillar } 4 \text { Strengthening the sustainability and competitiveness of SME } \\
\text { Dimension 3: Strengthening innovation in SME }\end{array}$ \\
\hline $\begin{array}{l}\text { 9. Principle: Enable SMEs to turn } \\
\text { environmental challenges into } \\
\text { opportunities }\end{array}$ & $\begin{array}{l}\text { Pillar } 4 \text { Strengthening the sustainability and competitiveness of SME } \\
\text { Dimension } 3 \text { Measure 2: Improve support for highly innovative } \\
\text { SMEs, eco-innovations, improving energy efficiency and efficient } \\
\text { use of resources }\end{array}$ \\
\hline $\begin{array}{l}\text { 10. Principle: Encourage and } \\
\text { support SMEs to benefit from the } \\
\text { growth of markets }\end{array}$ & $\begin{array}{l}\text { Pillar } 4 \text { Strengthening the sustainability and competitiveness of SME } \\
\text { Dimension } 4 \text { Measure 2: Creating new value systems and increasing } \\
\text { the degree of finalization of the product } \\
\text { Pillar } 5 \text { Improving access to new markets } \\
\text { Dimension 1: Providing continuous support to SME for entering } \\
\text { new markets }\end{array}$ \\
\hline
\end{tabular}

Source: The strategy for supporting the development of small and medium-sized enterprises, entrepreneurship and competitiveness for the period from 2015 to 2020, Government of the Republic of Serbia, March 2015, p.2 
Strategy 2008-2013 that is the precursor to the current SME Strategy, relied on five pillars. This five pillars included: promotion of entrepreneurship and establishment of new enterprises, development of human resources for the competitive SME sector, providing more sources of financing for small and medium enterprises, encouraging the competitiveness of this sector, and creating a better legal, institutional and business environment for the SME in the Republic of Serbia. This strategy was implemented through annual action plans prepared by the Ministry of Economy together with about thirty other institutions that were directly or indirectly involved in the implementation of the Strategy $08-13 .{ }^{11}$

The effects of all previous efforts by the Government of Republic of Serbia and other participants in improving the position of the SMEs throughout the transition period, which include the implementation of the Strategy 08-13, can be evaluated through the comparison of indicators on participation in employment of SMEs in the EU and Serbia. According to the data published in the magazine Business and Finance (24.12.2015.) under the title Small and Medium Enterprises - entrepreneurial guerrillas, USAID ${ }^{12}$ experts say the average number and participation in the number of employees in the EU according to the size of enterprises is similar in the EU and Serbia. In the European Union, out of 19.3 million enterprises, 99.8 percent are defined as SMEs and employ around 75 million people, or 66 percent of the total number of employees (6th Annual Report of the European Small Business Observatory). There are only 35.000 companies with more than 250 employees, while 18 million enterprises are of a small size and employ fewer than 10 workers. The average European business provides employment for four people, including the owner / director, with an annual turnover of around 500.000 euro, while the total turnover of the SMEs sector in the EU amounts to 56.2 percent of total turnover. From the standpoint of size, the structure of companies in Serbia is similar to the European Union, as $99.5 \%$ of the companies belong to the SME sector (Business Report of the Republic of Serbia in 2014, APR data). Most of them are micro enterprises (88.9\%), small ones are $9.4 \%$, medium $1.2 \%$, while large ones makeup only $0.5 \%$. Large enterprises employ a third of the total number of employees, and the rest employ SMEs, which is also in line with European practice. ${ }^{13}$

Speaking of agricultural production in Serbia, Table 2 shows the indices of agricultural production at the national level (which is a little less than $2 \%$ increased compared to the previous year, as well as indices by culture). It is noticeable that plant production grew by just under $6 \%$ compared to the previous year, while livestock production remained at the same level.

11 Stategija za podršku razvoju malih i srednjih preduzeća, preduzetništva i konkurentnosti za period od 2015. do 2020. godine, Vlada Republike Srbije, Službeni glasnik RS, Srbija, broj 55/11, 2014, (http://www.privreda.gov.rs/wp content/uploads/2015/06/Strategija-mala-isrednja-preduzeca.pdf) accessed on: 12.11.2017.

12 Biznis i finansije broj 122/203: Mikro i mala srednja preduzeća-Preduzetnička gerila, http://bif.rs/2015/12/biznis-i-finansije-broj-122123-mikro-mala-i-srednja-preduzecapreduzetnicka-gerila/, accessed on: 12.11. 2017.

13 Retrieved from: https://idea.usaid.gov/cd/serbia?comparisonGroup=region, accessed on: 12.11.2017. 
Table 2. Agricultural production indices, 2014/2013

\begin{tabular}{|l|l|}
\hline Plant production $(1,2,3)$ & 105,59 \\
\hline 1. Crop farming and horticulture (total) & 111,85 \\
\hline - Wheat & 119,86 \\
\hline - Industrial crop & 117,81 \\
\hline - Vegetables & 82,99 \\
\hline - Forage crops & 104,60 \\
\hline 2. Fruit growing & 79,54 \\
\hline 3. Wine growing & 72,78 \\
\hline Stockbreeding $(1+2+3+4+5)$ & 100,39 \\
\hline 1. Cattle raising & 99,94 \\
\hline 2. Hog raising & 104,84 \\
\hline 3. Sheep raising & 90,81 \\
\hline 4. Poultry & 100,48 \\
\hline 5. Beekeeping & 51,24 \\
\hline Agricultural production Total & 101,98 \\
\hline
\end{tabular}

Source: Statistical Office of the Republic of Serbia (SORS), to: Macroeconomic analysis and trends (MAT), no. 244, (April 2015)

According to economists, the fact that budget funds for agriculture were not affected by measures of fiscal restriction is encouraging, which has reduced negative trends in production, primarily in livestock breeding. According to the data from 2014, in the structure of the created value of agricultural production $70 \%$ comes from plant production, and 30\% from livestock production. For the competent Ministry of Agriculture, Forestry and Water Management, 4.15\% of budgetary funds or RSD 45.394.698.000 have been determined, of which RSD 1.569.220.000 for investment projects. $^{14}$

Last year, agriculture and food industry of Serbia participated in the creation of gross domestic product (GDP) of the country with about 17\%:

- agricultural production $10,6 \%$ and

— food industry $6.4 \%$.

However, if we consider the overall contribution of agriculture to other sectors of the economy, especially producers and processors of inputs and raw materials, this share exceeds $40 \%$ of total GDP. ${ }^{15}$

14 http:/www.mfin.gov.rs/UserFiles/File/zakoni/2013/Zakon\%20o\%20budzetu\%20RS\%20 za\%202014_\%20godinu.pdf, accessed on: 11.11.2017.

15 Research of the Library of the National Parliament of the Republic of Serbia (NSRS): Ownership and structure of agricultural land 2013. http://www.parlament.rs

EP 2017 (64) 4 (1537-1554) 


\section{Analysis of the most important measures of incentives to the development of agricultural production}

As already mentioned, the key institutional support to the agrarian sector ie. SME in Serbia is provided by the National Employment Service of the Republic of Serbia (NES), the Development Fund of the Republic of Serbia - SIEPA (today's Development Agency of Serbia - RAS), the Serbian Chamber of Commerce and the Government of Republic of Serbia as a creator all policies, measures and incentives related to the SME.

1. In addition to these basic functions, the National Employment Service as a public service for mediation in employment and insurance fund in the case of unemployment, creates a whole spectrum of so-called "active employment measures" aimed at, among other things, initiating entrepreneurship for unemployed persons. By raising the competencies of the unemployed persons, the NES, besides improving their skills, increases their chances of starting their own business.

According to the NES Work Plan for 2016 and the Law on the Budget of the Republic of Serbia ("Official Gazette of the Republic of Serbia" No. 103/215), funds are provided for the implementation of an active employment policy. These funds amount to 2.8 billion RSD, as well as from the budget fund for professional rehabilitation and incentives for employment of persons with disabilities in the amount of 550 million RSD (Table 3).

Table 3. Active measures of the National Employment Service for 2016.

\begin{tabular}{|l|l|l|l|l|l|l|}
\hline \multirow{2}{*}{ No. } & Measure & \multicolumn{3}{|l|}{ Planned number of persons } & \\
\cline { 3 - 7 } & & $\begin{array}{l}\text { Number } \\
\text { of persons } \\
\text { included in } \\
\text { the measures } \\
\text { of PWD } \\
\text { included } \\
\text { in the } \\
\text { measures }\end{array}$ & $\begin{array}{l}\text { Total number } \\
\text { of persons } \\
\text { included in } \\
\text { the measures }\end{array}$ & $\begin{array}{l}\text { *Number } \\
\text { of } \\
\text { employees }\end{array}$ & Effect \\
\hline 1. & $\begin{array}{l}\text { MEASURES OF } \\
\text { ACTIVE JOB SEARCH }\end{array}$ & 103,490 & 4,310 & 107,800 & 22,735 & $21 \%$ \\
\hline 1.1. & $\begin{array}{l}\text { Training for active job } \\
\text { search }\end{array}$ & 36,000 & 1,200 & 37,200 & 7,440 & $20 \%$ \\
\hline 1.1 .1$. & $\begin{array}{l}\text { Training for active job } \\
\text { search for qualified } \\
\text { persons }\end{array}$ & 24,845 & 700 & 25,545 & & \\
\hline 1.2. & Training of self-efficacy & 3,040 & 60 & 3,100 & 310 & $10 \%$ \\
\hline 1.3. & Job Search Club & 3,500 & 200 & 3,700 & 925 & $25 \%$ \\
\hline 1.4. & Job fair & 50,000 & 2,500 & 52,500 & 10,500 & $20 \%$ \\
\hline 1.5. & $\begin{array}{l}\text { Workshop for } \\
\text { overcoming stress due to } \\
\text { job loss }\end{array}$ & 950 & 50 & 1,000 & 50 & $5 \%$ \\
\hline 1.6. & $\begin{array}{l}\text { Training for } \\
\text { Entrepreneurship } \\
\text { Development }\end{array}$ & 10,000 & 300 & 10,300 & 3,510 & $34 \%$ \\
\hline
\end{tabular}




\begin{tabular}{|c|c|c|c|c|c|c|}
\hline 2. & $\begin{array}{l}\text { ADDITIONAL } \\
\text { EDUCATION AND } \\
\text { TRAINING } \\
\end{array}$ & 8,910 & 710 & 9,620 & 4,373 & $45 \%$ \\
\hline 2.1. & Professional practice & 5,000 & 40 & 5,040 & 2,210 & $44 \%$ \\
\hline 2.2 . & $\begin{array}{l}\text { Acquiring practical } \\
\text { knowledge }\end{array}$ & 280 & 20 & 300 & 300 & $100 \%$ \\
\hline 2.3. & Training & 2,100 & 650 & 2,750 & 1,539 & \\
\hline 2.3.1. & $\begin{array}{l}\text { Training for the labor } \\
\text { market }\end{array}$ & 1,100 & 630 & 1,730 & 519 & $30 \%$ \\
\hline 2.3.2. & $\begin{array}{l}\text { Trainings at the request } \\
\text { of employers }\end{array}$ & 1,000 & 20 & 1,020 & 1,020 & $100 \%$ \\
\hline 2.4 . & \begin{tabular}{|l|} 
Functional basic adult \\
education
\end{tabular} & 1,500 & 0 & 1,500 & 315 & $21 \%$ \\
\hline 2.5 . & $\begin{array}{l}\text { Acknowledgment of } \\
\text { previous learning }\end{array}$ & 30 & 0 & 30 & 9 & $30 \%$ \\
\hline 3. & $\begin{array}{l}\text { SUBSIDIES FOR } \\
\text { EMPLOYMENT } \\
\end{array}$ & 6,240 & 670 & 6,910 & 6,910 & $100 \%$ \\
\hline 3.1 . & $\begin{array}{l}\text { SUBSIDIES FOR SELF- } \\
\text { EMPLOYMENT }\end{array}$ & 3,350 & 160 & 3,510 & 3,510 & $100 \%$ \\
\hline 3.2. & $\begin{array}{l}\text { Subsidies for } \\
\text { employment of the } \\
\text { unemployed from the } \\
\text { category of hard-to- } \\
\text { employ }\end{array}$ & 2,690 & 110 & 2,800 & 2,800 & $100 \%$ \\
\hline 3.3 . & $\begin{array}{l}\text { Subsidies of part of } \\
\text { wages for beneficiaries } \\
\text { of financial social } \\
\text { assistance }\end{array}$ & 200 & 0 & 200 & 200 & $100 \%$ \\
\hline 3.4 . & $\begin{array}{l}\text { Wage subsidies for } \\
\text { people with disabilities } \\
\text { without work experience }\end{array}$ & 0 & 350 & 350 & 350 & $100 \%$ \\
\hline 3.5 . & $\begin{array}{l}\text { Support measures for } \\
\text { people with disabilities } \\
\text { who are employed under } \\
\text { special conditions }\end{array}$ & 0 & 50 & 50 & 50 & $100 \%$ \\
\hline \multirow[t]{2}{*}{4.} & PUBLIC WORKS & 5,000 & 1,900 & 6,900 & 6,900 & $100 \%$ \\
\hline & $\begin{array}{l}\text { ACTIVE LABOR } \\
\text { MARKET MEASURES } \\
\text { TOTAL } \\
(1+2+3+4)\end{array}$ & 123,640 & 7,590 & 131,230 & 40,918 & $31 \%$ \\
\hline
\end{tabular}

Source: http://www.nsz.gov.rs/live/digitalAssets/5/5039_program_rada_nsz_za_2016.pdf

When it comes to encouraging agricultural entrepreneurship, even a superficial view of this table shows that the National Employment Service (NES) does not have this issue clearly in focus. The total funds allocated to "active measures" of employment from the budget do not reach even 30 million euro for about 750,000 unemployed people on the NES records. Therefore, it is just under 4 euro per unemployed person per year. If you 
add the fact that out of all these active measures, entrepreneurs are targeted at only two (1.6 and 3.1), where only about 13.000 people are involved, it is clear that according to this, 2016 is not a "year of entrepreneurship" for NES.

When it comes to the effects of these programs, it is necessary to take them with a serious reserve, bearing in mind the fact that the data is created by the NES, which has a lot of interest in presenting the numbers better than they are in order to apply to the Government for additional funds in the next year. The current measures are already becoming archaic because they do not change for years or in any way follow current policies when it comes to the modern labor market.

2. Development Fund of the Republic of Serbia is one hundred percent state ownership and its purpose is primarily to encourage balanced regional development and improve the competitiveness of domestic economy and agriculture. The task of the Fund is to encourage the crafts production, service activities and employment by encouraging entrepreneurship, improving the liquidity of the domestic economy and contributing to the development of the capital market through its favorable credit lines. The Fund is financed mainly from the budget of the Republic of Serbia and the collection of already approved loans. His annual placement potential is around 55 million euro. The Development Fund policy consists in the distribution of different credit lines to the domestic economy, as a rule, under more favorable conditions than the market conditions (thus challenging one of the objectives of the Fund that relates to the contribution to the market of capital). ${ }^{16}$

The key weakness of the Development Fund over the entire period of its functioning is the distribution of funds under the strong influence of the politics. The harmful consequences of this arbitrary political interference in the management of the Development Fund are in the first place, uncollectible placements, the allocation of most of the funds to the small number of large private companies (close to politics) at the expense of entrepreneurs and start-ups and the occurrence of corrupt behavior in the allocation of funds. For these reasons, the Fund is forced to make new arrangements and forms of reprogramming, mutual settlement of obligations etc. with non-payments. When it comes to agricultural entrepreneurs, the conditions of the Fund for them were in some cases more stringent than with commercial banks, which the Fund often disqualified as an institution for supporting entrepreneurship.

3. Development Agency of Serbia (RAS) is a government agency that provides a wide range of services to investors, exporters and entrepreneurship. RAS continues the good practice of its legal predecessor SIEPA (Agency for Foreign Investment and Export Promotion), especially when it comes to supporting direct investments and export promotion. RAS has fairly limited resources for 2016 - around 17 million euro of the total budget, of which $3 / 4$ is allocated to various programs, including obligations for

16 More details on: http://www.fondzarazvoj.gov.rs/files/uslovi_TOS.pdf, accessed on: 09.11.2017. 
programs from previous years. ${ }^{17}$ The fact that the Government can increase the total amount of funds depending primarily on the inflow of foreign and domestic investments and the fiscal performance of the budget in the current year, should also be taken into account.

Bearing in mind the subject of this research, on this occasion we will focus more on the support RAS provides to entrepreneurship, aware that the key activities of this agency are nevertheless addressed to investors and exporters. RAS is one of the few institutions that has all the features of a modern service recognizable by its efficiency, speed and orientation towards the client. In this regard, for all praise is the attitude towards investors and the activities that the agency implements in promoting the export of Serbian agriculture. The most important programs, ie competitions and public calls for the allocation of funds for stimulating entrepreneurship in 2017 are:

Program for stimulating of balanced regional development in 2017 - the program is implemented by the Ministry of Economy in cooperation with the Development Agency, the financial framework amounts to 130 million RSD for local self-governments in order to develop various project technical documentation, strengthen regional competitiveness and co-finance membership fees for the work and business of accredited regional development agency.

Mentoring for agricultural cooperatives - A public call for the implementation of a standardized mentoring service is published in accordance with the Program of the Ministry of Economy - Standardized Service Pack (SSU) for micro, small and medium enterprises and entrepreneurs in 2017, implemented in cooperation with the Development Agency of Serbia (RAS) and through accredited development agencies.

- A program of support to businessmen through the Italian credit line the program of the Government of Italy, a financial framework of 30 million Euro that is realized through a domestic banking system aimed at strengthening local municipal services and the private sector. Loans between 5,000 and 1 million euro for entrepreneurship (up to 2 million euro for utility companies) are intended for the purchase of new and used equipment from Italian manufacturers.

- Small business support program for procurement of equipment - grants intended for improving the business and improving the competitiveness of the company, whereby up to $25 \%$ of the value of the purchased equipment is financed, ie maximum up to 2.5 million RSD. The total available funds under this program for 2017 are over 540 million RSD.

The program of support for the internationalization of companies, entrepreneurs and clusters - funds are aimed at improving the existing and development of new technological processes, new product and packaging design, participation in fairs, market research and others. The funds are allocated in the range of RSD 50.000

17 Retrieved from: http://ras.gov.rs/uploads/2016/07/informator-o-radu-ras-jul-2016-1.pdf, accessed on: 10.11.2017.

EP 2017 (64) 4 (1537-1554) 
to RSD 1 million for companies, or RSD 100.000 to RSD 2 million for clusters in agriculture. The amount of support is not more than up to $50 \%$ of the justified activity of the subject.

- Financial support to business institutional infrastructure - a program for clusters, chambers, business incubators and industrial parks for the development of business entities based on knowledge, innovation, competitiveness and business association. The total budget of the program is 130 million RSD, the approved funds range from 500.000 to 5 million RSD, or $50 \%$ of the reasonable costs.

START-UP Project - A program is designed for beginners in business and hardly employable categories such as young people, people over 45 years, people with disabilities, women and so on. The total budget is 100 million RSD, and is intended primarily for the purchase of equipment, by individually determining from 300 thousand to one million RSD. Users have to undergo training and mentoring.

\section{- Support program for further development of SMEs and entrepreneurs}

- total RSD 70 million intended for introduction of quality standards, certification or re-sertification, as well as obtaining the right to use the product logo (CE mark, FSC, CoC, etc.). This program also has a special component for encouraging women's entrepreneurship.

- Open competition for support to micro and small enterprises - incentive funds for 12 companies for up to 25.000 for a small, or 15.000 euro for a micro enterprise, in order to increase production and employment, with the applicants providing at least $30 \%$ of the funds in relation to the amount of the requested grant.

Based on the analysis of the available programs, it can be concluded that the intentions of the creators of these support are encouraging entrepreneurship, competitiveness and strengthening the technological equipment of the agricultural production sector, that is, the SME in the Republic of Serbia. Despite relative transparency, the problem of the volume of funds and the way they are distributed is always present. Some of the projects proposed in the RAS Information Bulletin, such as the Project "Year of Entrepreneurship" worth RSD 20 million, is reduced to the selection of one company (strategic partner or promoter) that will receive 15 million dinars to promote entrepreneurship in Serbia. This project is essentially "self-presentation" and promotion of the Government and its institutions, not entrepreneurship.

4. Chamber of Commerce and Industry of Serbia (CCIS) is certainly the institution with the largest tradition among the so far mentioned and its key role goes in four directions. First, Chamber represents its members before the Government and other state bodies and institutions. Second, it provides a full range of useful services to domestic and foreign companies including advising, mediating and informing. Third, improves economic cooperation with abroad by promoting Serbia as a good investment destination and organizing meetings of our and foreign companies through various arrangements. Finally, organizes different types of training and business education. 
All mentioned contributes to strengthening of competitiveness and enhancing the knowledge and skills of employees.

Certainly, the work of the CCIS can be given different critical assessments, starting from the financing method, bloated administration and the number of employees, as well as the strong influence of the politics on its work. Nevertheless, the role of the Chamber of Commerce is indispensable when it comes to helping the domestic economy by providing important information and services, especially through mediation in the establishment of international economic cooperation between states and businesses. CCIS has to develop a chamber system to position itself as "marketoriented" by creating different services to users in order to build independence and financial sustainability over the long run. Its sustainability is also a measure of the satisfaction of its users.

\section{The Government of the Republic of Serbia, the Ministry of Economy and the} Ministry of Agriculture are the creators of the country's economic and agricultural policy and the largest number of programs and measures for the improvement of entrepreneurship implemented through the aforementioned institutions. Indicators of economic growth, competitiveness, export of agricultural products, volume of investments and fiscal indicators best illustrate the efficiency of the economic policy of the Government, and ultimately, citizens who give or deny confidence in the elections. The government must do a lot to improve state aid control and incentives for entrepreneurship development. The whole system of incentives is centralized and still insufficiently transparent. The political influence on decision-making economic and entrepreneurship programs is still significant, which is a key factor that diminishes the efficiency and effectiveness of the proposed programs.

The resources available to the Republic of Serbia's budget are limited and insufficient to make significant progress when it comes to the development of entrepreneurship in agricultural production. It is also disputable how and in what way the funds from the scarce budget are being channeled. Should a state "invest in foreign investors" that open only low-paid jobs or should the state provide maximum support for entrepreneurship that will create sustainable jobs and self-employment of a large number of unemployed persons. Is it more important for the state to create a good business environment, reform the judiciary and education, reduce corruption, solve the problem of the bloated public sector, and finally end privatization or to engage in employment by paying for every opened job position. These are all open questions and dilemmas that lie ahead of the most responsible for the economic development of the country.

What is no longer questioned today, first step in the recovery of national agriculture, (within the agrarian and the SME sector) is education reform (the so-called "dual" model of education). In addition, when it comes to business and entrepreneurship in the agrarian sector, the second step is to promote and implement the concept of lifelong learning as a guarantee of sustainability of entrepreneurship in the "long term". Entrepreneurial education starts from primary school and continues even 
after graduation. The development of entrepreneurship is not based solely on formal education, but involves informal, which goes beyond the formal system. The spiral path of education points out not only that the learning process is not linear, but that in earlier years children faster and easier accept new knowledge, skills, behaviors and attitudes. The consequence is that this spiral is more compact at the beginning of our education, then when we are, for example, students. Going through each phase of education (primary, secondary, faculty, etc.), the scope of entrepreneurial spirit grows because of accumulated educational activities and increases the capacity of students to accept new knowledge and skills over time. What is more, depending on the age, children differently accept the development of different components of the entrepreneurial spirit (for example, in the elementary school, it is easiest and at the same time most important to influence the development of attitudes, while entrepreneurial knowledge and skills at this age are not so significant and important to develop). This is the same, but vice versa, when it comes to faculty: the key area of development is knowledge and skills, not attitudes and behaviors.

The measure that the Government intends to implement indicates changes in priorities, at least declaratively, which is certainly a good step forward. We will see the effects of all programs and measures through trends in agricultural production growth, as well as all other indicators of the national economy's performance, including the growth of citizens' living standards.

\section{Conclusion}

There will always be a dilemma whether and in what way the state should interfere with economic activities. Experience shows that state interventions in different times and circumstances can have positive effects, but they can also be very harmful. The outcomes and effects of certain state intervention depend on many factors as well as on the ability of the economic policy makers to correctly and at the right time place appropriate measures that can include various financial and non-financial incentives, including changes in regulations and the creation of a better economic environment. The Republic of Serbia has different experiences when it comes to "stimulating agrarian entrepreneurship". The socialist period and agriculture of the former Yugoslavia are characterised by ideological defect, failed agrarian reforms and colonization attempts on several occasions. The post-Yugoslav period is characterised by the break-up of the country, the criminalization of society, wild criminal-smuggling entrepreneurship and the economic disaster of most of the economies (except Slovenia) in the former country. The new millennium brings the era of "liberalism", speculative privatizations, opening up to the world, gradual economic growth, modest development of agricultural production, but still a relatively lagging behind the entire economic area of the former Yugoslavia. The 2008 economic crisis is the beginning of the abandonment of liberal mantras and the global strengthening of interventionism and protectionism in economies around the world. 
The Republic of Serbia must have a clear position when it comes to the concept of economic development and entrepreneurship. Our economic structure is not competitive with the surrounding countries, and especially with the world's largest economies, EU, China and the United States. It is therefore necessary to gradually liberalize economic relations with foreign countries in a way that maximally preserve domestic resources and agricultural entrepreneurship, and only after stabilization and strengthening allow an equal competitive game with global players. Therefore, Serbia must stimulate its agriculture with financial and non-financial measures. At the same time, everything should be done to eliminate numerous bureaucratic, administrative and para-fiscal barriers to the development of entrepreneurship as soon as possible. Incentives, accompanied by reforms in the judiciary and education, can in the long run strengthen agrarian entrepreneurship in Serbia by completely replacing the anachronistic structure from the end of the last century and introducing the country into a new stage of expansive development of agriculture.

So far, Serbia has not been able to find the right balance between different contradictory requirements, starting with those seeking the EU and the US in the direction of liberalization, through citizens' demands for better standards, social protection and infrastructure, to demands towards reducing tax burden, bureaucracy, corruption and the protection of the inefficient public sector.

If one finds "the smallest common denominator" of these demands, it is realistic to expect the beginning of a lasting recovery of agricultural entrepreneurship and its sustainability over a long period.

\section{Literature}

1. Avlijaš, R., (2010): Preduzetništvo, Univerzitet Singidunum, Beograd, Srbija.

2. Biznis i finansije broj 122/203: Mikro i mala srednja preduzeća-Preduzetnička gerila, (avalaible at: http://bif.rs/2015/12/biznis-i-finansije-broj-122123-mikro-mala-i-srednja-preduzeca-preduzetnicka-gerila/)

3. Ćeranić, S., (2014): Menadžment u malim i srednjim preduzećima, Fakultet za menadžment malih i srednjih preduzeća, Beograd, Srbija.

4. Dragutinović D., Filipović, M., Cvetanović, S., (2005): Teorija privrednog rasta i razvoja, Centar za istraživačku delatnost Ekonomskog Fakulteta, Beograd, Srbija,

5. Drucker, P., F., (1991): Inovacije i preduzetništvo-praksa i principi, Privatni pregled, Beograd, Srbija.

6. IDEA: Country dashboard-USAID Serbia, (available at:https://idea.usaid.gov/ $\mathrm{cd} /$ serbia? comparisonGroup=region) 
7. Nešković, S., (2016): An Agricultural Production as a Significiant Area of Strategy of Economy Diplomacy of Serbia, Journal Economics of Agriculture, Vol. LXIII, No 2(353-740), Institute of Agricultural Economics, Belgrade, Serbia.

8. Nešković, S., Jovanović, Ž., Čavlin, M., (2016): Economic Intelligence and Intellectual Capital in Agricultural Comptetitivness - Case Study, Journal Economics of Agriculture, Vol. LXIII, No 2 (353-740), Institute of Agricultural Economics, Belgrade, Serbia.

9. Stategija za podršku razvoju malih i srednjih preduzeća, preduzetništva i konkurentnosti za period od 2015. do 2020. godine, Vlada Republike Srbije, Službeni glasnik RS, Srbija, broj 55/11, 2014, (avalaible at: http://www. privreda.gov.rs/wp-content/uploads/2015/06/Strategija-mala-i-srednjapreduzeca.pdf)

10. Tesić,A., Ilić, V., Đelić, A., T., (2015): Labour Market in Serbia-An Opportunity or Limitation of Economic Growth, Journal Economics of Agriculture, October - December, Institute fo Agricultural Economics, Belgrade, Serbia.

11. Zakon o budžet za 2014. godinu, Službeni glasnik RS, Srbija, broj 110/13, 2013., (avalaible at: http://www.mfin.gov.rs/UserFiles/File/zakoni/2013/ Zakon\%20o\%20budzetu\%20RS\%20za\%202014_\%20godinu.pdf) 
ECONOMICS OF

AGRICULTURE

\section{CONTENT}

1. Adriana Radosavac, Desimir Knežević

ECONOMIC IMPORTANCE OF USE

OF PESTICIDES IN WHEAT PRODUCTION . . . . . . . . . . . 1323

2. Berhe Gebregewergs, Muuz Hadush

DOES CLIMATE CHANGE AFFECT PRICE OF VEGETABLES:

EVIDENCE FROM TIGRAI, NORTHERN MOST ETHIOPIA. . . . .1335

3. Grujica Vico, Aleksandra Govedarica-Lučić, Zoran Rajić, Radomir Bodiroga, Ivan Mičić, Silvija Zec Sambol, Marija Mičić

MULTI ATTRIBUTE ASSESSMENT APPROACH

IN VEGETABLE PRODUCTION . . . . . . . . . . . . . . 1355

4. Igor Trandafilović, Vesna Conić, Aleksandra Blagojević

IMPACT OF DEMOGRAPHIC FACTORS ON

ENVIRONMENTALLY CONSCIOUS PURCHASE BEHAVIOUR. . .1365

5. Imre Milán Harcsa

STUDY ON THE POTENTIAL OF SUBCONTRACT

PALINKA DISTILLATION . . . . . . . . . . . . . . 1379

6. Jelena Andrašić, Vera Mirović, Nada Milenković, Branimir Kalaš, Miloš Pjanić

IMPACT OF TAKEOVER PROCESS ON EMPLOYEES -

EVIDENCE FROM FOOD, RETAIL AND FINANCIAL SECTOR . . .1393

7. Jelena Birovljev, Danilo Đokić, Bojan Matkovski, Žana Kleut

ECONOMIC PERFORMANCES OF AGRICULTURE

OF CEFTA AND FORMER CEFTA COUNTRIES . . . . . . . . . . 1413

8. Jelena Marković, Svetlana Stevović

SUSTAINABILITY OF CHEMICAL SOIL QUALITY

IN SOUTHERN MORAVA RIVER VALLEY

IN CORELLATION WITH THE FLOODING $\ldots \ldots \ldots \ldots \ldots$ 
9. Mile Peševski, Zoran Milovančević

THE CHANGES IN THE USAGE OF AGRICULTURAL LAND

IN EASTERN REGION OF REPUBLIC OF MACEDONIA

BETWEEN $1991-2030 \ldots \ldots$. . . . . . . . . . . . . . . . . . . . . . .

10. Odjuvwuederhie Emmanuel Inoni, 'Oraye Dicta Ogisi, Felix Odemero Achoja

PROFITABILITY AND TECHNICAL EFFICIENCY IN HOMESTEAD

CATFISH PRODUCTION IN DELTA STATE, NIGERIA . . . . . . . 1449

11. Olja Munitlak - Ivanović, Jovan Zubović, Petar Mitić

RELATIONSHIP BETWEEN SUSTAINABLE DEVELOPMENT AND

GREEN ECONOMY - EMPHASIS ON GREEN FINANCE

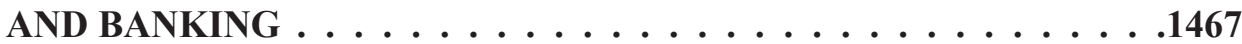

12. Petar Munćan, Dragica Božić

FARM SIZE AS A FACTOR OF EMLOYMENT AND INCOME

OF MEMBERS OF FAMILY FARMS . . . . . . . . . . . . . 1483

13. Rade Popović, Mira Kovljenić

EFFICIENCY OF WHEAT PRODUCTION ON FARMS

IN THE REPUBLIC OF SERBIA . . . . . . . . . . . . . . . . . . . . . . . . .

14. Radovan Damnjanović, Snežana Krstić, Milena Knežević, Svetislav Stanković,

Dejan Jeremić

THE DISCRIMINANT ANALYSIS APPLIED TO THE

DIFFERENTIATION OF SOIL TYPES . . . . . . . . . . . . 1513

15. Slavica Otović, Dunja Demirović, Kristina Košić, Aleksandra Vujko

FOSTERING ENTERPRENUERSHIP AT HIGH SCHOOLS:

A CASE OF RURAL AREAS IN VOJVODINA (SERBIA) . . . . . . .1523

16. Vladimir Ilić, Ivan Bauer, Anastazija Tanja Đelić, Aleksandar Nešković

INSTITUTIONAL SUPPORT FOR STRENGTHENING

ENTREPRENEURSHIP IN AGRICULTURAL PRODUCTION

OF THE REPUBLIC OF SERBIA . . . . . . . . . . . . . . . . . . . . . . . .

17. Boro Krstić, Zorica Vasiljević, Miroslav Nedeljković

INSURANCE CONTRACT AS THE BASIS FOR THE SAFETY OF

AGRICULTURAL PRODUCERS IN THE REPUBLIC OF SRPSKA • . 1555

18. Dejan Sekulić, Aleksandar Petrović, Vladimir Dimitrijević

WHO ARE WINE TOURISTS? AN EMPIRICAL INVESTIGATION

OF SEGMENTS IN SERBIAN WINE TOURISM . . . . . . . . . . . . . 
19. Milan Beslać, Ćorić Goran

FINANCIAL AND PRODUCTION ASPECTS OF GENETICALLY MODIFIED ORGANISMS $\ldots \ldots \ldots \ldots \ldots \ldots \ldots \ldots \ldots$

20. Mlađan Maksimović, Darjan Karabašević, Miodrag Brzaković, Pavle Brzaković THE EFFECTS RESULTING FROM THE APPLICATION OF THE CONCEPT OF THE SUSTAINABLE DEVELOPMENT OF RURAL TOURISM ON STARA PLANINA . . . . . . . . . . . . . . . .1595

21. Vesna Popović, Predrag Vuković, Milivoje Ćosić FOOD SAFETY AND QUALITY POLICY IN THE REPUBLIC OF SERBIA . . . . . . . . . . . . . . . . 1607

22. Radovan Pejanović, Danica Glavaš-Trbić, Mirela Tomaš-Simin PROBLEMS OF AGRICULTURAL AND RURAL DEVELOPMENT IN SERBIA AND NECESSITY OF NEW AGRICULTURAL POLICY . . . .1619

23. Saša Marković, Slavoljub Vujović, Aleksandar Damnjanović MARKETING AND HIGHER EDUCATION CONDITION IN SERBIA . . . . . . . . . . . . . . . . 1635

24. Semir Vehapi, Marina Milanović THE EFFECT OF MARKET ORIENTATION ON BUSINESS PERFORMANCE OF SERBIAN ORGANIC PRODUCERS . . . . . 1651

25. Suad Bećirović, Šemsudin Plojović, Enis Ujkanović, Senadin Plojović CHALLENGES AT STARTING AN AGRIBUSINESS IN THE HILLY MOUNTAINOUS REGIONS OF SOUTHWEST SERBIA . . . . . . . .1669

26. Vladimir Zakić, Vlado Kovačević, Jelena Damnjanović SIGNIFICANCE OF FINACIAL LITERACY FOR THE AGRICULTURAL HOLDINGS IN SERBIA . . . . . . . . . . 1687

27. Željko Bjelajac, Marijana Dukić Mijatović, Željko Vojinović PROTECTION OF LAND IN THE REPUBLIC OF SERBIA AND ECOLOGICAL SECURITY WITH REGARD TO STRATEGIC AND LEGAL FRAMEWORKS . . . . . . . . . .1703 